\title{
Music Composition in the Music Curriculum
}

\author{
Michel Hogenes \\ The Hague University of Applied Sciences, The Hague, The Netherlands; \\ Codarts, Rotterdam School of Music, Rotterdam, The Netherlands \\ Bert Van Oers \\ VU University, Amsterdam, The Netherlands \\ René F. W. Diekstra \\ The Hague University of Applied Sciences, The Hague, The Netherlands; \\ University College Roosevelt, Middelburg, The Netherlands
}

\begin{abstract}
In contrast to other arts subjects, music education focuses foremost on the re-production of music, rather than the production of their own pieces of art. This article is a theoretical study, in which the possibilities to regard children as composers are explored. Three research questions are inquired: 1. What is music composition? 2. To what extent does music composition require the mastery of music notation and creativity? and 3. What are the pedagogical implications of music composition as a regular classroom activity? It is concluded that an activity theory interpretation of music composition and creativity can provide a productive basis for the implementation of music education in elementary school classrooms. A three-step-model was described for engaging and assisting students in collaborative composition activity. The authors argue that, with the help of this model, every classroom teacher should be able to work with students on music composition. It offers classroom teachers tools to motivate, stimulate, and facilitate students in working on challenging assignments, which offer them insight in musical concepts and develop their musical skills.
\end{abstract}

Keywords: composition process, creativity, cultural historical activity theory, music composition, music notation

\section{Introduction}

Although music is everywhere around us and is also easy to attain from of computers, tablets, and mobile phones, the number of children that is active in music making lags behind the number of children that solely listens to music (Hogenes, 2012a). Since the inception of convent schools in the 18th century, singing is an activity that takes place in schools. However, music as a school subject in elementary schools includes, in addition to singing and playing instruments, the domain of active listening. Music notation, music and movement, and talking about music are derived from making music and/or listening, but can also be regarded as independent domains, like music-making and listening.

Looking closely at the domain of music-making, it is evident that music is mostly re-produced in schools,

Michel Hogenes, B.M., lecturer, Teacher Education Department, The Hague University of Applied Sciences; Codarts, Rotterdam School of Music.

Bert Van Oers, Ph.D., professor, Department of Theory and Research in Education, VU University Amsterdam.

René F. W. Diekstra, Ph.D., professor, head, Department of Youth and Development, The Hague University of Applied Sciences; Roosevelt Academy, University College Roosevelt. 
while in other arts subjects (like visual art, dance, drama, and literature), creation or production plays an important role. Music composition executed by children themselves is not a regular classroom activity in most music education practices in elementary schools. Classroom observations showed that students like to sing songs written by songwriters and also like to play pieces written by composers (Hogenes, 2010a). They enthusiastically perform music and are interested in the music that is offered to them. But why not introduce music composition as a classroom activity and regard children as young composers?

The comparison of music education with other arts subjects raised the question whether an approach of music education, in which music composition, as a practice of playful music-making, plays a key role, can also be implemented in elementary schools in ways that make sense to the students. The main question addressed in this article is: How can elementary school students be meaningfully engaged in music composition activities? In order to answer this question, three preliminary questions should be answered first:

1. What is music composition?

2. To what extent does music composition require the mastery of music notation and creativity?

3. What are the pedagogical implications of music composition as a regular classroom activity?

In this article, we will bring different theoretical fields together in order to develop an approach to music education that concentrates on "composing" as a core activity, and that is relevant for elementary school teachers. Our theoretical framework with regard to learning and development will be the cultural-historical activity theory of Vygotsky and Leont'ev.

\section{What Is Music Composition?}

The word "composition" refers both to a process (the act of making up music) and a product (the resulting music) (Kratus, 2012). A composer is the person who creates new pieces of music. The word "composer" derives from the Latin words "com" and "ponere", which literally means "one who puts together". Composing music can be done by using musical notations or from an oral tradition. Music composition can be conducted for interpretation and performance, or through direct manipulation of sonic materials. The roles of composers and performers can be distinct, but can also be merged. Barrett (2003) described the composition process as an intensely personal process of meaning-making (Bruner, 1986), and with regard to children's meaning-making in the domain of music, she wrote:

Musical meaning-making is an accomplishment of the child who-as musician and composer - is engaged in a dialogue with self and the emerging musical work, a dialogue that is mediated by the culture. The constant dialogue — among the roles of composer, critical listener, and performer - forms the heart of musical meaning-making. (pp. 23-24)

The words "composition", "creativity", and "improvisation" are often used interchangeably, which can make discussions on this subject diffuse (Kors \& Van de Veerdonk, 2006). Both composition and improvisation can be creative processes (Kiehn, 2003). It should be added, however, that both activities can also be taught in a very uncreative way. According to Kratus (2012, p. 372), the difference between composition and improvisation is that the act of composition allows time for reflection, development, and revision of the final product, while the act of improvisation does not. Kratus (2012) noted that improvisation is sometimes defined in terms of composition, as simultaneous composition and performance. He pleaded to define composition in a more accurate way in terms of improvisation, i.e., as improvisation that allows time for reflection, development, and revision. In this study, we define composition as a planned and deliberate 
realization of a creative process with a new piece of music as the outcome (Campbell \& Scott-Kassner, 2006). However, there are also other, sometimes more specific, definitions of the word "composing". Berkley (2004), for example, described composing as knowledge-rich, complex, multiple, and creative problem-solving, requiring the development of skills of hypothesis and verification in students. Berkley (2004) stated that teaching composing is characterized in the main activities of instruction and training in composing skills and knowledge, management of a positive and creative learning environment, and facilitation of ownership, autonomy, and authority in students. She concluded that conceptualizing teaching composing as problem-solving enables music educators to rationalize the specific demands of the curriculum context, in which they are operating by providing students with a framework for cognitive development in composing.

An improvisation, however, is a section or a piece that is invented spontaneously. It is created real-time, but not formalized, refined, or repeated. Therefore, it is never written like a composition. However, improvisation can be the first step in the composition process. Instant composing is a form that is between composition and improvisation. It combines (group) improvisation and the performance of reproducible parts. Improvisation exercises are used to create musical materials that lead to a composition made by students and a music leader/workshop leader (Connect, 2005; Frowijn \& Tomassen, 2007; Green, 2008).

Studies on children as composers are not absent in literature; researchers have typically examined either the process or products of composition, or examined both (Barrett, 1996; 1997; Burnard, 1995; 1999; Delorenzo, 1989; Folkstad, 1996; Folkstad, Hargreaves, \& Lindstrom, 1998; Freed-Garrod, 1999; Henderson, 2007; Kaschub, 1997; Kratus, 1989; 1994; 2001; Miller, 2004; Ruthmann, 2008; Stauffer, 2001; 2002; Wiggins 1994; Wilson \& Wales, 1995). However, although there is a strong believe in the value of creative activities for all children, and in music composition in particular, composing music is still not a regular classroom activity despite all attention the topic has had over the last 30 years.

As said, many researches have been devoted to composition processes. Wallas (1926) distinguished four stages of the composition process: preparation, incubation, illumination, and verification. These stages have been quoted in more recent literature (Hargreaves, 1986; Kennedy, 2002; Kratus, 1989; Sloboda, 1985). Webster (1990) used Wallas' four stages in the construction of his theory of creativity. Sloboda (1985) restricted the process of composition to two stages: inspiration and execution. Both stages involve conscious and unconscious operations. Emmerson (1989) constructed two models based on his experience with electro-acoustic music. The first and simplest model consists of three phases: (a) action (to create/combine sounds); (b) test (listen and determine whether the sounds sound good together); and (c) accept (store) or reject (modify as new action). His second model includes three new steps: new action, action repertoire, and reinforcement. These supplementary stages allow composers to use either rule-oriented (conscious/learned) or intuitive (unconscious) bases for decisions made as a result of the test phase (Kennedy, 2002). An approach popular in the Netherlands is the Guildhall approach adopted from the Connect Project by the Guildhall School for Drama and Music in London. The Guildhall approach uses five steps in the the process of composing: warm-up, interpretation, composition, improvisation, and performance (Connect, 2005).

Research has also been done on composition processes in specifically professional composers. Bennett (1976) interviewed eight professional composers and identified six stages: germinal idea, first sketch, first draft, elaboration and refinement, completion of the final draft, and score copying. Hung (1998) researched the processes of 16 Taiwanese composers and reported several successful approaches: listen-analyse-compose; listen-play-compose; receive stimulation-introspect-breakthrough; and sense/observe-imagine-express/create. 
Hung (1998) concluded that mastery of composition relies on persistent effort and an accumulation of experience. He also concluded that there is no standard compositional procedure.

These studies described above show that music composition, as a form of music production, is a complex activity that can be executed by both adults and children and has many appearances. It is a planned and deliberate realization of a creative process with a new piece of music as the outcome. In the text below, we describe how classroom teachers and music specialists can organize this process.

\section{To What Extent Does Music Composition Require the Mastery of Music Notation and Creativity?}

\section{Music Notation}

It is a misconception that composition always concerns "writing of music". Musical repertoire of non-Western countries can be good examples of the rejection of this misconception. Much popular music is also not written down. Music notation is often used as a means to facilitate the reproduction of a music composition. This music notation does not necessarily have to be modern staff notation. It can also be written down with, for example, graphic notations. However, the forms of music notation are often needed for the music composition process.

Not only general classroom teachers, but also music educators often debate the use of music notation. Should children learn to read a music score or not? Is musical literacy as important as "normal" literacy and numeracy? Although researchers still debate the best methods and techniques for teaching children to read language, they agree that language reading could be best achieved through speech, after the basic structure and vocabulary of the language have first been established (Cooper, 2003; Tomasello, 2003). In music education, the first steps of the musical literacy process (listening to sounds and music and active music production by singing) are often neglected, or children are not given enough time to establish a basic structure and vocabulary in music (Hogenes, 2010a). In analogy to the functions of composing texts (i.e., to write down a person's thoughts coherently and to structure ideas and form meta-cognition) (Vygotsky, 1978), basic musical literacy can also be considered useful in the process of music composition. Musical notation, then, is not only used to make other people perform a composition, but also used to reflect on one's own composition.

Bruner (1964) introduced three modes of representation: enactive representation, iconic representation, and symbolic representation. For enactive representation, Bruner meant a mode of representing past events through appropriate motor response. A simple musical example of this kind of representation is a young child shaking a rattle. The child represents a past event through motor response. Although the rattle might have fallen or removed, the child makes the shaking movements, as if the movement itself produce the accustomed sound. Iconic representation is the first step to the use of abstract signs. Iconic representation is where information is represented visually in the form of images. Graphical notation of music is a form of iconic representation. The use of traditional staff notation is a form of symbolic representation. This is where sounds are stored in the form of codes and symbols, like the function of written language (Vygotsky, 1978).

Barrett (1997) studied the use of idiosyncratic symbols (invented notations) of young children to encode their composition experiences. Barrett viewed these symbols as vehicles for conveying meaning and precursors to the development of culturally agreed symbol systems of the adult literature world. The outcome of the study suggested that as children become more experienced in encoding their responses, their recordings become less context-bound and more concerned with ideas and concepts. 
In the coda of a study on musical literacy conducted by Mills and McPherson (2006), the authors noted:

In the final analysis, it is important to acknowledge how many children learn to read staff notation and achieve a level of proficiency that enables them to function musically. Equally, however, many children are failed by the ways in which they are taught to read music, and give up playing completely. Reading staff notation is not a prerequisite for successful engagement with and appreciation of music, and exclusive concentration on reading has held back the progress of countless learners, while putting many others off completely. (p. 169)

Despite this strong warning of Mills and McPherson (2006), Hogenes (2010b) stated that musical literacy will emerge in music activities when the musical environment of children shows that music notation is an integral part of this musical environment and is useful in executing these activities. Observations show that children are curious to the artifacts used by adults (Vygotsky, 1978). Participating in social-cultural activities, like music-making and music composition, offers children opportunities to explore these artifacts and use them for their own benefits. Adults/teachers can challenge children to participate in meaningful musical activities, in which musical notation can play a major role.

Music notation in the process of music composition as a classroom activity is a useful means to let children coherently write down their thoughts and to structure their ideas. Moreover, they can use music notation for meta-cognitive processes, such as planning, monitoring, and evaluation. It is one of the tools that they can use to reflect on the music they composed.

\section{Creativity}

Musical literacy is often conceived as a collection of technical skills necessary for music-making. Western classical performing musicians have developed their literacy skills through childhood instrumental lessons that addressed instrumental skills, music reading skills, and related skills as part of the same package (Mills \& McPherson, 2006). Like music composition, musical literacy can be taught in an uncreative way, for example, by teaching the duration of notes as if mathematics, without a musical context. How can these skills be developed is a more creative approach.

Moran and John-Steiner (2003) described Vygotsky's (1978) ideas regarding the development of the creative imagination over the lifespan and the role of creativity in cultural development. Like play does for children, creativity creates a lifelong zone of proximal development for adults to continually learn from and contribute to their cultures. It helps people actively adapt themselves to the environment and modify the environment to themselves: "The dialectical approach, while admitting the influence of nature on man, asserts that man, in turn, affects nature and creates through his changes in nature new natural conditions for his existence" (Vygotsky, 1978, p. 60). Through such interaction, creativity actualizes inherent and latent possibilities of people and environments; it not only broadens what we singly and collectively have done, but also what we can and may do. It allows people to step out of the present moment, reflect on the past, and plan future behaviors; it connects us to what could be, or can imagine to be. Through the development of creativity, a person comes to be a flexible and intentional inventor of his/her personal future and a potential contributor to his/her cultural endowment. Creativity is not a priori stable property of only special people, but a positive and essential capability of all healthy-functioning individuals. It transforms both the creator through the personal experience of the process, and transforms other people via the creation of knowledge and innovative artifacts propagated through the culture to be appropriated by others. Creativity is both the goal and the means of personal and cultural development (Moran \& John-Steiner, 2003, pp. 63-64). 
A substantial body of literature on creativity and musical creativity in particular is available (Beghetto \& Kaufman, 2010; Binkley, Erstad, Herman, Raizen, Ripley, \& Rumble, 2010; Craft, 2001; Elliot, 1995; Gardner, 2007; Hargreaves, Miell, \& MacDonald, 2012; National Advisory Committee on Creative and Cultural Education (NACCCE), 1999; Webster, 1987; 1990). However, the expression "musical creativity" is interpreted in many different ways. Creativity in general is described as the ability to generate something new (unusual, unique, offering new perspectives, varied, original, different from the usual, and pattern-breaking) that has value (useful, effective, efficient, and addition to the society) (Ten Hoonte, 2009). There are also descriptions of creativity, though, that do not require originality and/or something completely new, but rely on what is already in place (Karkou, 2012). Karkou and Sanderson (2006) defined creativity as the capacity to find new and unexpected connections, new relations, and therefore, new meanings (adapted from Stanton-Jones, 1992; Smitskamp, 1995). Burnard (2012) stated that: "musical creativity-broadly constructed as the exemplary locus of diverse forms of practice - is one of the most prominent yet notoriously contentious phenomena produced in the field of music education" (p. 319).

Webster (1990) developed a specific theory on creative thinking in music. This theory includes three qualities of divergent thinking: (a) musical extensiveness (the number of ideas that are generated); (b) flexibility (the ease with which students shift between musical parameters); and (c) originality (the uniqueness of musical ideas). The three qualities described above interact with others, like children's musical understandings, sensitivities, and abilities, such as to imagine pitches and rhythms, aesthetic sensitivity, and the ability to craft a piece to effect the final product of the creative effort.

As illustrated above, the expression "musical creativity" is interpreted in many different ways. Elliot (1995) made a clear distinction between the concepts of creativity and originality. For Elliot (1995), creating is "a particular kind of making or doing that results in tangible products or achievements that people deem valuable, useful, or exceptional in some regard" (p. 216). Originality, however, is achieved when a work of art is "simultaneously similar to, yet different from, its relevant ancestors" (Elliot, 1995, p. 217). It is not the sole determiner of creativity; the product or achievement's significance to its domain is of equal importance (Brophy, 2000).

The question whether musical creativity is required for being involved in music composition can only be answered in relation to composition activities/assignments given to students. As said before, music composition can be taught in a very uncreative way, like music composition as a closed assignment. The intention of the authors of this article is to regard students as young composers, not as executors of assignments. Children are creative beings, and appropriate conditions that facilitate children's potential to generate new ideas and retain some of them for further elaboration have to be realized in classrooms. Sometimes, however, their creativity may have to be stimulated, for example, when children are not used to be involved in creative activities or their initiatives are not appreciated by adults/teachers.

\section{Towards a Cultural-Historical Activity Theory Interpretation of Music Composition}

How do we create meaningful music activities for elementary classrooms? Leont'ev $(1981 ; 1983)$ described meaningful education as a form of education, in which two elements must be distinguished: cultural meaning (the cultural value) and sense (personal meaning and value in the light of personal motives and interests). In meaningful music activities, students build a repertoire of cultural knowledge and skills with respect to a subject to learn, for example, composing music or playing flute, and connect this with personal 
interests and values (sense). Teachers offer professional (culturally accepted) tools to students that can be made personally relevant for these students. Meaningful (music) learning is fundamental for learning that aims to promote broad cultural development and agency. Learning is only meaningful for children when it makes sense to them and actually contributes to their potency of action (Van Oers, 2012a, p. 19).

Children potentially have huge developmental potentials. However, they need assistance to improve their abilities for participation in social-cultural practices. For young children, play is an important mode of participation in social-cultural activities (Vygotsky, 1978; Van Oers, 2012a). The desire of children to be part of and to participate in the world of adults is their incentive for development and learning. In their play, they can do this because they have freedom to imitate adults' activities in their own way.

In line with the thoughts of Vygotsky (1978; 1982; 1997), El'konin (1978; 1989), Leont'ev (1981; 1983), etc., play can be characterized as a specific mode of human activity, defined by determinants that form the activity format of play: rules, degrees of freedom, and intense involvement and experience (Van Oers, 2013). As can be observed in meaningful activities for older children and adults, the activity format of play can be used for all age groups (Aldrich, 2009; DeRose, 2009; McFeetors \& Mason, 2009; Kaufman \& Sauve, 2009; Piu \& Fegola, 2010). The authors of this article used the format of play to develop the concept of music composition activities (Hogenes, Van Oers, \& Diekstra, 2012).

\section{Music Composition as a Regular Classroom Practice-Design of a Teaching Strategy}

Referring to the approaches described above (Frowijn \& Tomassen, 2007; Connect, 2005; Green, 2008), one can ascertain that these approaches fit the characteristics of the activity format of play: rules, degrees of freedom, intense involvement, and experience. Music composition can be a meaningful tool for music education in schools. Given the (Dutch) situation that only few schools have music specialists, the question is how to create a usable strategy for the implementation of music composition as a regular classroom activity that can be conducted by classroom teachers.

Within education, based on the cultural-historical activity theory, "broad development" of children is an important issue besides the development of specific knowledge and skills needed for making or understanding music. Broad development is meant a multi-faceted person formation ("Bildung") that leads to an increasing self-reliance of a participant involved in cultural practices. Looking at the key subject "reading and writing", in cultural-historical curricula, one can note that children deal with the concepts of main ideas, sequencing, classification, and categorizing (Pompert, 2004). Composing music in elementary schools can also assist students to gain control over these intellectual strategies by brainstorming (in groups and as individuals), writing rough drafts, editing and revising, and creating finished products (Wiggins, 1990). Like in many other subject matter domains, music education can make a step from a reproductive approach to a more productive one. In the activity of music composition, we see children brainstorm, write draft versions of music, and adjust and revise compositions in order to get a presentable result. Perlmutter's (2010) classroom observations confirmed this point of view. She noticed that students love to create and to be involved in improvisational activities. Composition and improvisation help them show what musical concepts they understand from what they are told during the lessons. Wiggins (1990) offered four reasons to compose music with children: 1 . Children have a congenital creativity. They are proud of their own creations and have fun in making these, which stimulate their motivation; 2. Composing music can support children to become proud of their musicality; 3. Composition is an excellent didactical tool to teach musical concepts and to reinforce pre-existing ones; and 
4. The analysis of children's compositions offers teachers insights in developing understandings of musical concepts.

\section{A Composition Process in Three Steps}

Building on previous analyses of music composing activity and taking into account that general classroom teachers should be able to conduct music composition as a regular classroom activity, we adopted and adjusted a model for text composition that is used in Dutch schools for cultural-historical education for the core subject "reading and writing" (Pompert, 2004). We adapted this three-step-model for composing music (Hogenes, 2012b):

1. Creation of a common base;

2. Creating ideas and writing the composition;

3. Presentation and publication or recording;

How these three steps are implemented in music education is described below.

Step 1-Creation of a common base. Based on the concept of "common knowledge" (Edwards \& Mercer, 1987; Mercer, 1995), the first step in our three-step-model for music composition in schools starts with the creation of a common base. Common knowledge refers to the construction of knowledge as essentially a social process. It is important for children to know the usefulness and necessity of writing a text and to have an idea of ways to write this text. Just like for text composition, these issues also play a major role in composing one's own music. Although most people are daily confronted with music, but not everyone is aware of what they hear. This is what marketing people make advantage of, or what is used to make people feel at ease in elevators and train stations. It is also used to chase young people away with classical music because they prefer other kinds of music, and to, for example, communicate meaning and further the narrative in a film (Juslin \& Sloboda, 2001, p. 258).

Music (sounds, putted in a form, and having meaning for humans) consists of three aspects: sound, form (musical structures), and meaning (Lei, Haverkort, \& Noordam, 2010). Composers can use these aspects in order to create a piece of music. For the formation of a composition, it is necessary to bring form into the sounds that are available to a composer. For this, three aspects of form are available: repetition, contrast, and variation. The third aspect of music - meaning, has two different specifications: (a) the function of music (dance music, music to march on, etc.); and (b) emotions. Although one piece of music can generate different emotions in different people, a composer uses certain sounds and forms to create, for example, energetic music or exciting music.

To get children composing their own music, it is necessary to give them some input. Just giving them an assignment is not enough to get started in most cases. There has to be an incentive to start composing music. Building a common basis around an interesting theme in which the children do feel the need to compose their own music and to write it down is very important. Working on a common theme, such as spooky music, film scoring, radio play, etc., can do this. Starting the composition process with a recorded or a written composition or a drama activity may also serve to create a common base. Other possibilities (e.g., stories, pictures, paintings, poetry, listening or talking about aspects of sound (pitch, duration, and tone color)), aspects of form (e.g., repetition, contrast, variation, ostinato, phrase, motive, rondo, layered, theme and variations, blues, and free form), and aesthetic ideas (e.g., density, texture, tension, and release) can be good starting points.

Here is an example: 
Soraya teaches music as a music specialist in a public school (the 6th grade, 10 years old students). She has chosen to make a composition with the students like the American saxophonist John Zorn (born in 1953) had done. In October 1984, he finished a composition called "Cobra". This unpublished, but recorded composition consists of a set of cues notated on cards. The musicians play the card or cards that are shown by the musical leader. The person that leads the piece can be considered both conductor and composer. Using cards, the "conductor" can assign the orchestra to play soft, fast, and gentle. The musicians improvise their music by following the assignments on the cards. The conductor can subsequently show the card faster and add the card angrily. The piece will get a completely new sphere. Part of the class is the audience that has the role of critical friends that gives feedback to the musicians and the conductor. Soraya used the Cobra activity to let students explore aspects of sound and form. After the Cobra activity, the students had to write a piece of music based on musical contrasts.

Step 2-Creating ideas and writing the composition. The second step focuses on providing children with opportunities to explore sound, form, and meaning, and support children in this process. Children will develop routines in exploring music in a save pedagogical climate, which will lead to an optimum production of music and sounds. A teacher is a participant in the music composition process and helps children orientate; improve and deepen the activity; broaden skills and ideas; add new action potential; and last but not least, reflect on the composition. If this works, the next step will be to write down the music. This can be done not only in traditional music notations, but also in a graphical or pictorial way.

The role of the teacher in this process is to offer support for a draft version: To help the children who have difficulties get started and the children who need support for other reasons and/or have questions. The teacher is the partner of the children in their creative processes, who has more skills and knowledge than the children and gives impulses including asking questions to get the children to wanting new action potential (their zone of proximal development) and to support the learning of the new actions and concepts that emerge within this zone of their activities.

All children contribute to the music composition process. However, they can have several roles in this process, such as composer, performer, critical friend, etc.. Music composition can be realized optimally when students learn to play relevant roles in cultural practices (called "imitative participation") and are assisted to critically appropriate the tools and rules that are required for the accomplishment of these roles (Van Oers, 2012b). Some students prefer to take the role of composer. Some prefer to become musicians, performers, or conductors. Others have strong technical skills and use these skills to record the music composition or use their computer skills to score and publish the composition. In this way, all students participate in music composition as a meaningful activity. Of course, students should not only do the things they like most or are already good at. Roles will have to circulate, so students will broaden and deepen their knowledge, skills, and attitudes in the context of varying roles once they have successfully experienced music composition. The authors of this article observed that students were aware that all roles are equally important to make the composition activity a success. They like to contribute to the process in different roles.

A significant part of this second step of the composition process (creating ideas and writing the composition) is the revision phase. The revision of a piece of music is always focusing on the goal to make students reflect on their compositions and to help them improve the draft version of their composition. The revision can be done not only individually, but also with the class as a whole. In the last option, all students should have a copy of the notated music. It should also be performed live, or there should be a recording of the 
composition. The revision takes place in three rounds, in which the expert musician or the teacher should play a guiding role by asking critical questions as long as the students do not adopt this role of reviewer/critic (It is important to emphasize here that the playful mode of the composing activity should not be destroyed by the experts' participation):

1. On the ideas of the composer and the content of the piece. "Does the music sound as it was meant?". There can be differences in the experiences of the composer and the audience and/or musicians. The composer should be asked for his/her experiences, as well as the audience/performers. If the music sounds different from its intent, what can be done to make the music sound like it was meant?

2. The construction of the piece and its style. This second round is about the technical aspects of a composition. "What musical form is chosen?", "Is there a logical construction of the piece?", "What musical tools can the composer use to make the music more scary or gay?", and "Is it possible for the musicians to perform what the composer wants, or not?". Questions like these can be used to make students think about the construction and style of their compositions.

3. The notation of the music. The last revision round is about musical notation (pictorial, graphic, or traditional). Musical notation is a means, not a goal on its own. "Is it possible for other people to perform the piece, based on what is written?", "Are there more simple ways of notating what you have written?", and "Do you want me to show how a classical composer would have written this cadenza?".

The teacher leads the revision by asking specific questions to regulate questions of the other students and making the children respond on each other's questions to keep a safe atmosphere. All children correct the music on their copies. This whole process will lead to the students' final version.

If music composition is a meaningful activity for children, they want to learn and improve their compositions on all aspects above. The teacher has a mediating role between creating a meaningful activity and the educational goals she/he wants to reach. Music composition is not only a challenging activity, but also an activity in which children can meaningfully appropriate certain musical concepts and skills. To become a good composer, a lot of exercise is necessary. The teacher's role is to motivate, stimulate, and facilitate the process that leads to compositions that students will be proud of.

Step 3-Presentation and publication or recording. It is easier to see the usefulness and necessity of composing music when one has an audience for its music. A persistent eagerness to produce music and to improve one's compositions will be hard for any child without a guarantee that its music is listened to and is discussed. Live performances of compositions are very motivating for (young) composers. With modern electronic equipment, it is also possible to publish or record the music. Both scores and recordings are easy to distribute by digital means. Many children in upper grades of elementary schools have mobile phones. Most of these phones have recording capabilities. Of course, there is also more advanced equipment to record music. These recordings will have better sound quality than mobile phones.

Apart from the role of composers, musicians and audience are needed to improve (revision) and perform music. Distribution of roles and identification with these roles are of great importance (Stanislavski, 1968). Students will fulfill alternately the different roles needed for the creation and performance of music.

\section{Conclusions}

The drive for students' creative involvement in cultural practices can be found in the desire of children to be part of and to participate in the world of adults, according to a basic assumption of cultural-historical activity 
theory. This is their incentive for development and learning. Play offers people the opportunity to take part in practices in their own way, due to the essential degrees of freedom in play. This activity format of play offers people of all ages the opportunity to engage in imaginative situations and intense experience. On the basis of these theoretical assumptions, we construed "composing" as a playful cultural practice following some musical rules, allowing the participants some degrees of freedom and raising high levels of personal involvement. Through playful participation in a composing practice with experts, new comers can learn and improve the rules and appropriate relevant knowledge and skills. From this point of view, we conceive of the composing process as a planned, deliberate, and realization of a creative process with a new piece of music as the outcome (Campbell \& Scott-Kassner, 2006). Pedagogical implications of music composition as a regular playful classroom activity are that the participating and guiding expert (teacher) should never impair the quality of the activity as play, i.e., the expert should abide by the characteristics of the activity format of play-rules, degrees of freedom, and intense experience. The article describes a pedagogical model consistent with this play-based approach as a three-step-model, in which step 1 is the creation of a common base, step 2 is creating ideas and writing the composition, and step 3 is the presentation and publication. An important part of the process is the revision phase, part of step 2. In this phase, the teacher focuses on the goal to make students think about their compositions and to help them improve their compositions.

Using the developed model for music composition, every classroom teacher should be able to work with students on music composition. It offers classroom teachers tools to motivate, stimulate, and facilitate students in working on challenging assignments, which offer students insight in musical concepts and develop musical skills. The presumed potential of this pedagogical model is that it can enhance meaningful musical learning in elementary school students. The validity of this theoretically construed claim can only be verified by further empirical research in which the model is implemented in everyday elementary classrooms.

\section{References}

Aldrich, C. (2009). Learning online with games, simulations, and virtual worlds: Strategies for online instruction. San Francisco, C.A.: John Wiley.

Barrett, M. (1996). Children's aesthetic decision-making: An analysis of children's musical discourse as composers. International Journal of Music Education, 28, 37-62.

Barrett, M. (1997). Invented notations: A view of young children's musical thinking. Research Studies in Music Education, 8 , $2-14$.

Barrett, M. (2003). Freedoms and constraints: Constructing musical worlds through the dialogue of composition. In M. Hickey (Ed.), Why and how to teach music composition: A new horizon for music education (pp. 3-27). Reston, V.A.: MENC.

Beghetto, R. A., \& Kaufman, J. C. (Eds.). (2010). Nurturing creativity in the classroom. Cambridge, U.K.: Cambridge University Press.

Bennett, S. (1976). The process of musical creation. Journal of Research in Music Education, 24, 3-13.

Berkley, R. (2004). Teaching composing as creative problem solving: Conceptualising composing pedagogy. British Journal of Music Education, 21(3), 239-263.

Binkley, M., Erstad, O., Herman, J., Raizen, S., Ripley, M., \& Rumble, M. (2010). Draft white paper 1: Defining 21st century skills. Retrieved from http://atc21s.org/wp-content/uploads/2011/11/1 Defining 21st-Century-Skills.pdf

Brophy, T. S. (2000). Assessing the developing child musician: A guide for general music teachers. Chicago, I.L.: GIA Publications.

Bruner, J. S. (1964). The course of cognitive growth. American Psychologist, 19(1), 1-15.

Bruner, J. S. (1986). Actual minds, possible worlds. Cambridge, M.A.: Harvard University Press.

Burnard, P. (1995). Task design and experience in composition. Research Studies in Music Education, 5, 32-46.

Burnard, P. (1999). Bodily intention in children's improvisation and composition. Psychology of Music, 27, 159-174. 
Burnard, P. (2012). Commentary: Musical creativity as practice. In G. E. McPherson, \& G. Welch (Eds.), The Oxford handbook of music education (Vol. 2, pp. 319-336). New York, N.Y.: Oxford University Press.

Campbell, P. S., \& Scott-Kassner, C. (2006). Music in childhood: From preschool though the elementary grades. Boston, M.A.: Schirmer.

Connect. (2005). Transforming musical leadership. London: Musical Futures. Retrieved from http://www.musicalfutures.org.uk

Cooper, D. (2003). Literacy: Helping children construct meaning (5th ed.). New York, N.Y.: Houghton Mifflin.

Craft, A. (2001). Creativity in education. London, U.K.: Continuum.

Delorenzo, L. C. (1989). A field study of sixth-grade students' creative music problem-solving processes. Journal of Research in Music Education, 37, 188-200.

DeRose, J. J. (2009). Remnants from the past: Using scrapbooks to make U.S. hitory personal and meaningful. Social Education, $73,240-243$.

Edwards, D., \& Mercer, N. (1987). Common knowledge: The development of understanding in the classroom. London, U.K.: Methuen.

El'konin, D. B. (1978). Psichologija igry (The psychology of play). Moscow: Pedagogika.

El'konin, D. B. (1989). K problem periodizacii psichiceskogo razvitija v detskom vozraste (The problem of periodization of the psychological development of the child). In D. B. El'konin (Ed.), Izbrannye psichogiceskie trudy (Collected pychological works) (pp. 60-77). Moscow: Pedagogika.

Elliot, D. J. (1995). Music matters: A new philosophy of music education. New York, N.Y.: Oxford University Press.

Emmerson, S. (1989). Composing strategies and edagogy. Contemporary Music Review, 3, 133-144.

Folkestad, G. (1996). Computer based creative music making: Young people's music in the digital age. Göteborg: Acta Unisitatis Gothoburgensis.

Folkestad, G., Hargreaves, D. J., \& Lindstrom, B. (1998). Compositional strategies in computer-based music making. British Journal of Music Education, 15(1), 83-97.

Freed-Garrod, J. (1999). Cognitive processes and music composing: A descriptive case study from ongoing conversations with Peter. Bulletin of the Council for Research in Music Education, 142, 81-82.

Frowijn, R., \& Tomassen, H. (2007). Muziek zonder noten (Music without notes). Utrecht: HKU.

Gardner, H. (2007). Five minds for the future. Boston, M.A.: Harvard Business School Press.

Green, L. (2008). Music informal learning and the school: A new classroom pedagogy. Hampshire, U.K.: Ashgate.

Hargreaves, D. J. (1986). The developmental psychology of music. Cambridge, U.K.: Cambridge University Press.

Hargreaves, D. J., Miell, D. E., \& MacDonald, R. A. R. (2012). Musical imaginations: Multidisciplinary perspectives on creativity, and perception. Oxford, U.K.: Oxford University Press

Henderson, C. (2007). Music to measure: Symbolic representations in children's composition. Waikato Journal of Education, 13, 197-210.

Hogenes, M. (2010a). Towards composing as a classroom activity. The Learning Teacher Magazine, 2, 13.

Hogenes, M. (2010b). The child as composer. Beijing: ISME.

Hogenes, M. (2012a). Muziek in de bovenbouw (Music in the upper grades). Mensenkinderen, 132(27), 27-29.

Hogenes, M. (2012b). Componeren in de bovenbouw van de basisschool (Composition in the upper grades of elementary education). Zone, 11(1), 10-13.

Hogenes, M., Van Oers, B., \& Diekstra, R. F. W. (2012). Playing music (Unpublished thesis, The Hague University of Applied Science).

Hung, Y. C. (1998). An exploration of the musical composition background/experience, process, and pedagogy of selected composers in Taiwan (Doctoral dissertation, Columbia University Teacher's College).

Juslin, P. N., \& Sloboda, J. A. (2001). (Eds.). Music and emotion: Theory and research. Oxford, U.K.: Oxford University Press.

Karkou, V. (2012). Aspects of theory and practice in dance movement psychotherapy in the UK: Similarities and differences from music therapy. In R. MacDonald, G. Kreutz, \& L. Mitchell (Eds.), Music, health \& wellbeing. Oxford, U.K.: Oxford University Press.

Karkou, V., \& Sanderson, P. (2006). Arts therapies: A research-based map of the field. Edinburgh, U.K.: Elsevier.

Kaschub, M. (1997). A comparison of two composer-guided large group composition projects. Research Studies in Music Education, 8, 15-28. 
Kaufman, D., \& Sauve, L. (2009). Educational gameplay and simulation environments: Case studies and lessons learned. Hershey, P.A.: Information Science Publishing.

Kennedy, M. A. (2002). Listening to the music: Compositional processes of high school composers. Journal of Research in Music Education, 50(2), 94-110.

Kiehn, M. T. (2003). Development of musical creativity among elementary school students. Journal of Research in Music Education, 51(4), 278-288.

Kors, N., \& Van de Veerdonk, H. (2006). Componeren in de basisschool (Composition in the elementary school). Amsterdam: Hogeschool Voor de Kunsten.

Kratus, J. (1989). A time analysis of the compositional processes used by children ages 7 to 11. Journal of Research in Music Education, 37, 5-20.

Kratus, J. (1994). Relationships among children's music audiation and their compositional processes and products. Journal of Research in Music Education, 42, 115-130.

Kratus, J. (2001). Effects of available tonality and pitch options on children's compositional processes and products. Journal of Research in Music Education, 49, 294-306.

Kratus, J. (2012). Nurturing the songcatchers. In W. D. Bowman, \& A. L. Frega (Eds.), Handbook of philosophy in music education (pp. 367-385). Oxford, U.K.: Oxford University Press.

Lei, R., Haverkort, F., \& Noordam, L. (2010). Muziek meester! (Music teacher!). Baarn/Utrecht/Zutphen: ThiemeMeulenhoff.

Leont'ev, A. N. (1981). The problem of activity in psychology. In J. V. Wertsch (Ed.), The concept of activity in Soviet psychology (pp. 37-71). Armonk, N.Y.: M. E. Sharpe.

Leont'ev, A. N. (1983). Psichologičeskie osnovy doškol'noj igry (Psychological bases of toddler play). In A. N. Leont'ev, Izbrannie psichologičeskie proizbedenija, T. 1 (Selection of the psychological works, part 1) (pp. 303-323). Moscow: Pedagogika.

McFeetors, P. J., \& Mason, T. (2009). Learning deductive reasoning through games of logic. Mathematics Teacher, 4, $284-290$.

Mercer, N. (1995). The guided construction of knowledge: Talk amongst teachers and learners. Clevedon: Multilingual Matters.

Miller, B. A. (2004). Designing compositional tasks for elementary music classrooms. Research Studies in Music Education, 22, 59-71.

Mills, J., \& McPherson, G. E. (2006). Musical literacy. In G. E. McPherson (Ed.), The child as musician. A handbook of musical development. Oxford, U.K.: Oxford University Press.

Moran, S., \& John-Steiner, V. (2003). Creativity in the making: Vygotsky's contemporary contribution to the dialectic of creativity \& development. In R. K. Sawyer, V. John-Steiner, S. Moran, R. J. Sternberg, D. H. Feldman, J. Nakamura, \& M. Csikszentmihalyi (Eds.), Creativity and development (pp. 61-90). New York, N.Y.: Oxford University Press.

National Advisory Committee on Creative and Cultural Education (NACCCE). (1999). All our futures: Creativity, culture and education. London, U.K.: DfEE.

Perlmutter, A. (2010). Improve for everyone. Teaching Music, 17(6), 30-35.

Piu, A., \& Fegola, C. (2010). Simulations and gaming for mathematical education: Epistemology and teaching strategies. Hershey, P.A.: Information Science Publishing.

Pompert, B. (2004). Thema's en taal: Voor de bovenbouw (Themes and language: For the upper grades). Assen: Van Gorcum.

Ruthmann, S. A. (2008). Whose agency matters? Negotiating pedagogical and creative intent during composing experiences. Research Studies in Music Education, 30(1), 43-58.

Sloboda, J. A. (1985). The musical mind: The cognitive psychology of music. Oxford, U.K.: Oxford University Press.

Smitskamp, H. (1995). The problem of professional diagnosis in the arts therapies. The Arts in Psychotherapy, 22(3), $181-187$.

Stanislavski, K. S. A. (1968). Creating a role. London, U.K.: Mentor.

Stanton-Jones, K. (1992). An introduction to dance movement therapy in psychiatry. London, U.K.: Tavistock/Routledge.

Stauffer, S. L. (2001). Composing with computers: Meg makes music. Bulletin of the Council for Research in Music Education, 150, 1-20.

Stauffer, S. L. (2002). Connections between the musical and life experiences of young composers and their compositions. Journal of Research in Music Education, 50(4), 301-322.

Ten Hoonte, J. (2009). Creatief denken (Creative thinking). Rotterdam: Codarts.

Tomasello, M. (2003). Constructing a language. A usage-based theory of language acquisition. Cambridge, M.A.: Harvard Unbiversity Press.

Van Oers, B. (2012a). Developmental education for young children: Concept, practice and implementation. Dordrecht: Springer. 
Van Oers, B. (2012b). Meaningful cultural learning by imitative participation: The case of abstract thinking in primary school. Human Development, 55(3), 136 - 158.

Van Oers, B. (2013). Is it play? Towards a reconceptualisation of role-play from an activity theory perspective. European Early Childhood Education Research Journal, 21(2), 185-198.

Vygotsky, L. S. (1978). Mind in society: The development of higher psychological processes. Cambridge, M.A.: Harvard University Press.

Vygotsky, L. S. (1982). Het spel en zijn rol in de psychische ontwikkeling van het kind (Play and its role in the psychological development of the child). Pedagogische Studiën, 59(1), 16-28.

Vygotsky, L. S. (1997). Educational psychology. Boca Raton, F.L.: St. Lucie Press.

Wallas, G. (1926). The art of thought. New York, N.Y.: Harcourt Brace and Co..

Webster, P. (1987). Refinement of a measure of creative thinking in music. In C. K. Madsen, \& C. A. Prickett (Eds.), Applications of research in music behavior (pp. 257-271). Tuscoloosa, A.L.: The University of Alabama Press.

Webster, P. (1990). Creativity as creative thinking. Music Educators Journal, 76(9), 22-28.

Wiggins, J. (1990). Composition in the classroom: A tool for teaching. Reston: MENC.

Wiggins, J. H. (1994). Children's strategies for solving compositional problems with peers. Journal of Research in Music Education, 42, 232-252.

Wilson, S. J., \& Wales, R. J. (1995). An exploration of children's musical compositions. Journal of Research in Music Education, $43,94-111$. 